Research Article

\title{
INVESTIGATION OF MICROSTRUCTURE AND MICROHARDNESS PROPERTIES OF CO AND CR REINFORCED NIAL INTERMETALLIC COMPOUND PRODUCED BY SHS METHOD

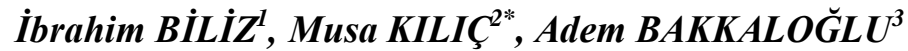

\begin{abstract}
In this study, the porous samples were manufactured through selfpropagating high-temperature synthesis (SHS) by adding $10 \%$ Co and Cr to $50 \% \mathrm{Ni}-50 \% \mathrm{Al}$ powders. $10 \% \mathrm{Co}$ and $\mathrm{Cr}$ added $50 \% \mathrm{Ni}-50 \% \mathrm{Al}$ samples were mixed for 12 hours using a mixer with a rotational speed of $300 \mathrm{rpm}$ and compacted under $100 \mathrm{MPa}$ pressure. The obtained samples were then synthesized by moving them to an argon atmosphere and combusted with the aid of a tungsten electrode. The obtained samples after the combustion reaction were characterized in terms of their microstructure using scanning electron microscope - the backscattered electrons (SEM$B S E)$. The elemental and phase analysis were carried out using EDS and $X R D$, respectively. The Energy-dispersive spectroscopy (EDS) results showed that the dominant element was $\mathrm{Ni}$ and the presence of $\mathrm{Co}$ with $\mathrm{Cr}$ was less than that of Al. As a result of XRD analyses, it was determined that NiAl was formed as the dominant phase in the samples and also Ni3Al and NiAl3 phases were formed in low amounts. Both $\mathrm{Cr}$ and Co addition increased hardness of NiAl alloy. However, Cr has a greater effect on the increase of hardness values than Co.
\end{abstract}

Key words: SHS, NiAlCo, NiAlCr, Microstructure, Microhardness

\section{Introduction}

Properties such as resistance to temperature, corrosion resistance at high temperatures and resistance to oxidation, which are among the desired properties in equipment operating at high temperatures are presence in the NiAl intermetallic material [1-3]. Therefore, its produce for mass production and put into use has an important place in industrial sense [4-6]. Reaction synthesis method, which is a low cost, easy to install and use method, which does not require external energy and thus does not cause environmental damage, has started to attract great attention in obtaining NiAl and $\mathrm{Ni3} \mathrm{Al}$ intermetallic compounds [7-9].

Problems such as brittleness, improvement of mechanical properties, limiting the use of $\mathrm{NiAl}$ intermetallic alloy cover a significant part of the researches for the development of these materials. The most important of these problems is the brittleness of these materials and thus the restriction of

\footnotetext{
1 Department of Metallurgical and Materials Engineering, University of Batman, Batman, Turkey, (ibrahim.biliz@batman.edu.tr) iD https://orcid.org/0000-0002-9090-4905

2 Department of Machinery and Manufacturing Engineering, University of Batman, Batman, Turkey, (musa.kilic@batman.edu.tr) iD https://orcid.org/0000-0002-5808-6917

3 Department Metallurgical and Materials Engineering, University of Yildiz Technical, İstanbul, Turkey, (ejt@ineseg.org) https://orcid.org/0000-0002-7148-2567
} 
forming [2]. In the researches, $\mathrm{Cr}$, which is indicated to increase toughness and ductility, and Co, which is indicated to increase porosity and hardness, were investigated by adding to $\mathrm{NiAl}$, and the hardness values of the produced samples were investigated $[2,5,10,11]$. The aim of this study is to investigate the effect of $\mathrm{Co}$ and $\mathrm{Cr}$ element added to $\mathrm{NiAl}$ powder compound on microstructure and microhardness properties of NiAl. At the same time, microstructure image by SEM-BSE, elemental analysis by EDS and phase components were determined by XRD analysis.

\section{Materials and Method}

$\mathrm{Ni}, \mathrm{Al}$, Co and $\mathrm{Cr}$ metal powders used in alloy production were obtained from a commercial company. Information on these metal powders is given in Table 1.

Table 1: Properties of metal powders used in laboratory

\begin{tabular}{lcccc}
\hline Materials & Purity (\%) & $\begin{array}{c}\text { Powder Size } \\
(\text { mesh })\end{array}$ & $\begin{array}{c}\text { Melting } \\
\text { Temperature } \\
\left({ }^{\circ} \mathrm{C}\right)\end{array}$ & $\begin{array}{c}\text { Specific Weight } \\
\left(\mathrm{gr} / \mathrm{cm}^{3}\right)\end{array}$ \\
\hline Aluminum & 99,99 & -325 & 660 & 2,700 \\
Nickel & 99,99 & -325 & 1453 & 8,908 \\
Cobalt & 99,99 & -325 & 1495 & 8,920 \\
Chromium & 99,99 & -325 & 1875 & 7,190
\end{tabular}

In this study, every step of the laboratory studies was carried out in Argon atmosphere. In the glove box, a mixture of $\mathrm{Ni}$ and $\mathrm{Al}$ element powders prepared in the atomic ratios given in Table 2 and $10 \% \mathrm{Co}$ and $\mathrm{Cr}$ powders were added. The prepared powder mixtures were mixed in the mixing mill at $300 \mathrm{rpm}$ for 12 hours [12]. Table 2 shows the atomic and mass ratios and theoretical densities of $\mathrm{Ni}$, $\mathrm{Al}, \mathrm{Co}$ and $\mathrm{Cr}$ powder mixtures.

Table 2: Atomic and theoretical densities of powder mixtures

\begin{tabular}{ccccc}
$\begin{array}{c}\text { Mixture } \\
\text { Number }\end{array}$ & Powder Mixture & Atomic Ratio & Weight & Theoretical Density \\
& & & Ratio & \\
\hline 1 & NİAl & $\% 50 \mathrm{Ni}-\% 50 \mathrm{Al}$ & $\% 76,74 \mathrm{Ni}$ & $5,804 \mathrm{~g} / \mathrm{cm}^{3}$ \\
& & & $\% 23,26 \mathrm{Al}$ & \\
\hline 2 & $\mathrm{NiAlCo}(10)$ & $\% 45 \mathrm{Ni}-\% 45 \mathrm{Al}-\% 10 \mathrm{Co}$ & $\% 65,56 \mathrm{Ni}$ & $6,11 \mathrm{~g} / \mathrm{cm}^{3}$ \\
& & & $\% 19,88 \mathrm{Al}$ & \\
& & & $\% 14,56 \mathrm{Co}$
\end{tabular}

\begin{tabular}{|c|c|c|c|c|}
\hline \multirow[t]{3}{*}{3} & \multirow[t]{3}{*}{$\mathrm{NiAlCr}(10)$} & \multirow[t]{3}{*}{$\% 45 \mathrm{Ni}-\% 45 \mathrm{Al}-\% 10 \mathrm{Cr}$} & $\% 67,45 \mathrm{Ni}$ & \multirow[t]{3}{*}{$5,94 \mathrm{~g} / \mathrm{cm}^{3}$} \\
\hline & & & $\% 20,45 \mathrm{Al}$ & \\
\hline & & & $\% 12,10 \mathrm{Cr}$ & \\
\hline
\end{tabular}

The powder mixtures obtained at the end of this process were compressed in a cylindrical mold by cold press with a pressure of $100 \mathrm{MPa}$. Pre-and post-ignition (raw and synthesized) pictures of compacted 10\% alloy doped NiAl raw samples are given in Figure 1. 


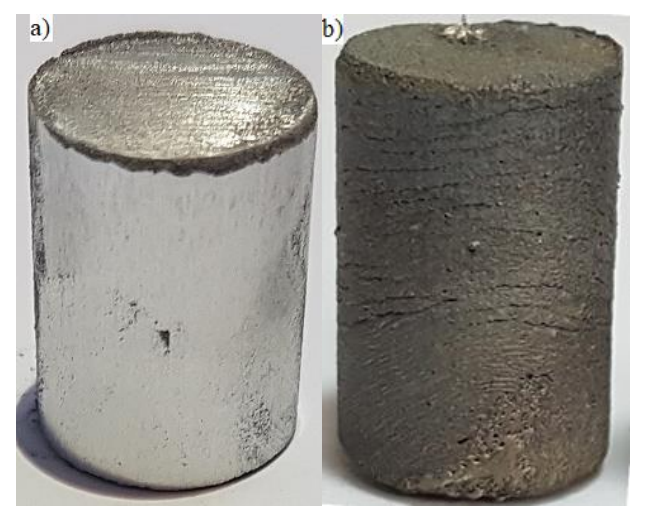

Figure 1: a) Raw sample b) Synthesized sample

The device for preheating and igniting the pressed samples in argon atmosphere was designed and produced. Ignition unit consists of preheating chamber, ignition center and chamber, temperature control knob and argon gas inlet-outlet sections. The scheme of the production by SHS method is given in Figure 2.

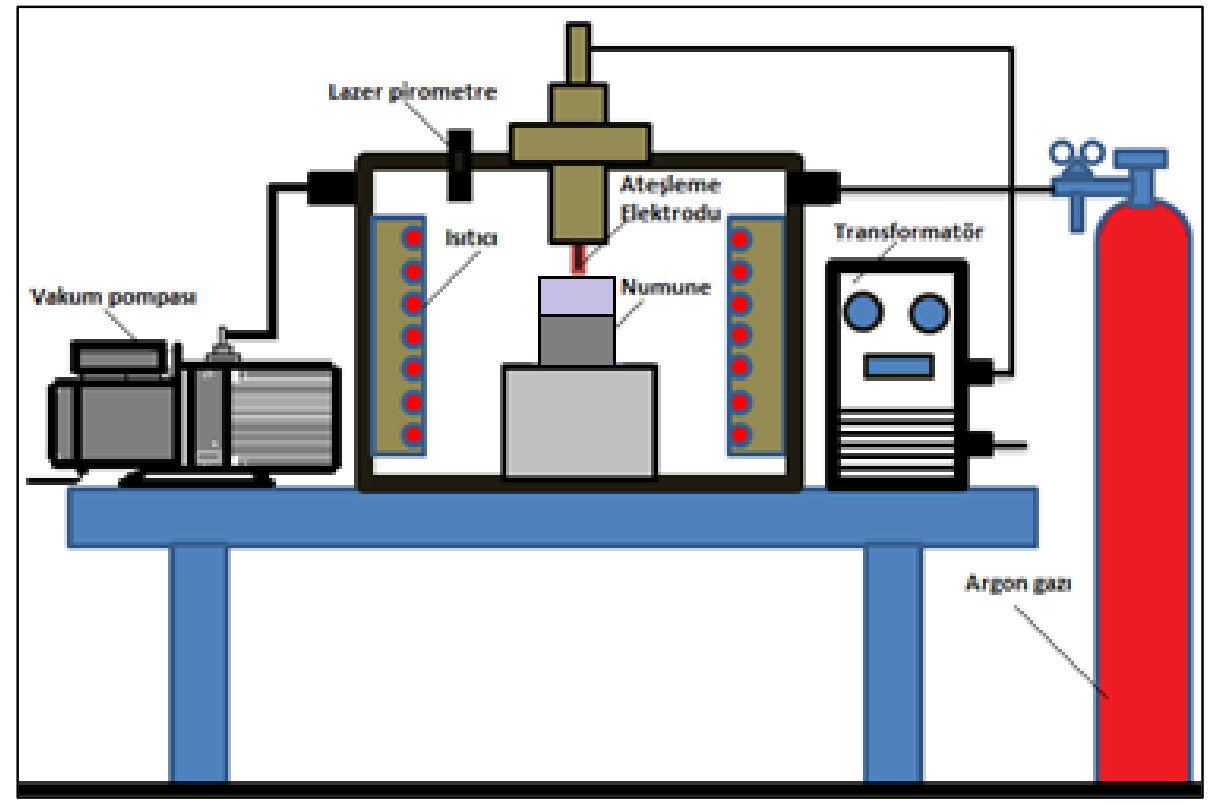

Figure 2: The scheme of ignition unit[13]

The external heat, which would allow the self-synthesis of the compacted samples, was given by ignition in the firing chamber under argon atmosphere. Samples were cut on the cutting disc for metallographic analysis after synthesis.

The cut samples were polished using 240, 400, 600, 800, 1000 and 1200 mesh sanders. After prepolishing, the samples were polished with $1 \mu \mathrm{m}$ size diamond paste solution for final polishing. For the microstructure analysis of the polished samples, etch of $33 \mathrm{wt} \% \mathrm{HF}, 33 \mathrm{wt} \% \mathrm{HNO}_{3}, 33 \%$ water solution was used. Leica brand optical microscope, Jeol brand SEM-BSE and EDS elemental analysis devices were used for microstructure analysis of samples after etching. The phase compositions were determined using $\mathrm{Cu} \mathrm{K \alpha}$ radiation and the sample in horizontal position ( $2 \theta$ angles: 10 to $120^{\circ} \mathrm{C}$ ) using Rigaku MiniFlex. Shimadzu brand microhardness tester with $20 \mathrm{~g}\left(\mathrm{HV}_{0.02}\right)$ loading was used to obtain microhardness values. 


\section{Results and Discussion}

In this study, samples were obtained by adding $\mathrm{Co}$ and $\mathrm{Cr}$ to $\mathrm{NiAl}$ powder mixture. Microstructures and microhardness values of these samples were determined. In this method, which is similar to powder metallurgy production methods, porosity decreases as a result of increasing contact of powder particles with pressing [14]. It is thought that the rapid synthesis reaction may increase the pore ratio since there is no time for shrinkage of the samples. In addition, addition of $\mathrm{Co}$ and $\mathrm{Cr}$ alloy elements changed the porosity rates. As a result of the calculations, the porosity ratio of unalloyed $\mathrm{NiAl}$ was determined as $27.17 \%$. However, the NiAl intermetallic material with $10 \%$ Co added was $28.25 \%$ due to the effect of Co element. However, the addition of $10 \% \mathrm{Cr}$ reduced this porosity by $9.83 \%$ and was found to be $25 \%$. It is found that $\mathrm{Co}$ and $\mathrm{Cr}$ additive increases microhardness values at different rates.[12] The addition of Co and $\mathrm{Cr}$ triggers the formation of NiAl3 and Ni3Al phases. Formation of NiAl3 and Ni3 Al changes hardness because the hardest point of $\mathrm{Ni3} \mathrm{Al}$ is almost $500 \mathrm{HV}$ and NiAl3 harder than Ni3 Al about $200 \mathrm{HV}$.

The lowest point of hardness of $\mathrm{NiAl}$ as a function of stoichiometry is when Ni/Al is 1 and it is $330 \mathrm{HV}$ [12].The $\mathrm{Cr}$ additive reduced the porosity relatively, and the Co additive was found to increase the pore ratio further. These data and the data in the literature support each other. [11,15-19]. Microhardness measurements taken from $\mathrm{Cr}$ and $\mathrm{Co}$ reinforced samples are given in Figure 3. According to the hardness measurement results, the highest hardness value obtained in the $\mathrm{Cr}$ alloyed samples as $578 \mathrm{HV}$ and $523 \mathrm{HV}$ for Co alloyed samples while hardness of NiAl is between 279-339 $\mathrm{HV}$ according to studies.[12The mean hardness of Cr alloyed samples was 77.6 HV harder than the mean hardness of Co alloyed samples. In addition, the value range of the measurements taken in $\mathrm{Cr}$ reinforced samples has a narrower range than Co reinforced samples. The reason for this is thought to be that the phases in the structure of $\mathrm{Cr}$ reinforced samples are less and the number of phases in Co reinforced samples is higher. In addition, the porosity of the material is one of the factors affecting this situation.

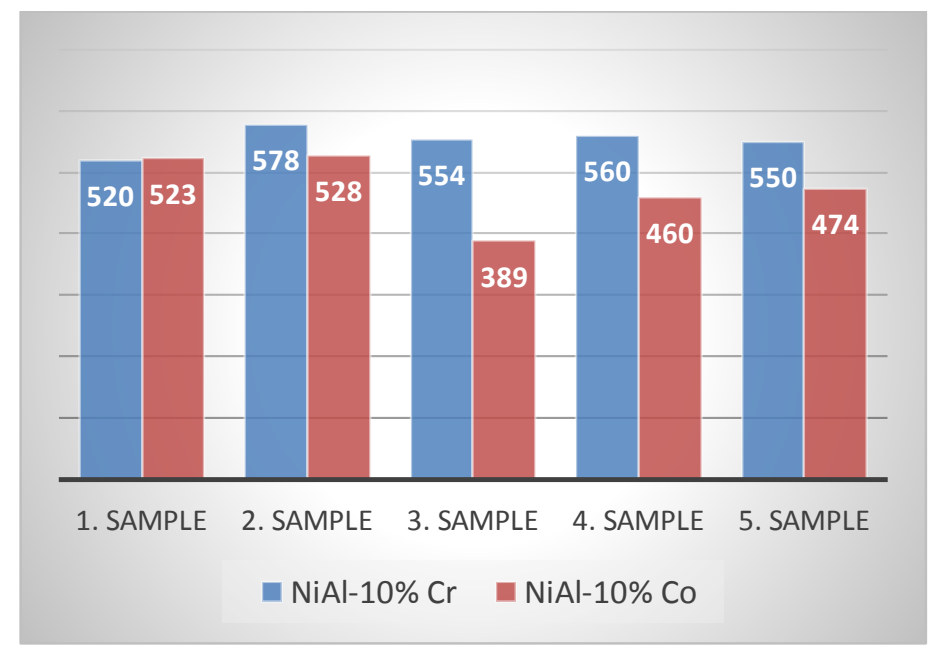

Figure 3: $\mathrm{Co}$ and $\mathrm{Cr}$ reinforced $\mathrm{NiAl}$ intermetallic compounds microhardness values

SEM, BSE and optical microscope images and XRD, EDS graphs of $\mathrm{Cr}$ and Co reinforced NiAl alloys are given in Figure 4 and Figure 5. The porous structure of the produced materials can be seen in SEM and optical microscope views. The composition ratios of the samples in the EDS results confirm the alloying element ratios in the produced samples. 
In the XRD analysis, $\mathrm{NiAl}$ and $\mathrm{Ni}_{3} \mathrm{Al}$ phases and low $\mathrm{NiAl}_{3}$ phases were detected in $\mathrm{Cr}$ alloyed $\mathrm{NiAl}$ sample. On the other hand, more $\mathrm{NiAl}$ phase and low $\mathrm{Ni}_{3} \mathrm{Al}$ and $\mathrm{NiAl}_{3}$ phases were detected in the Co alloyed NiAl sample

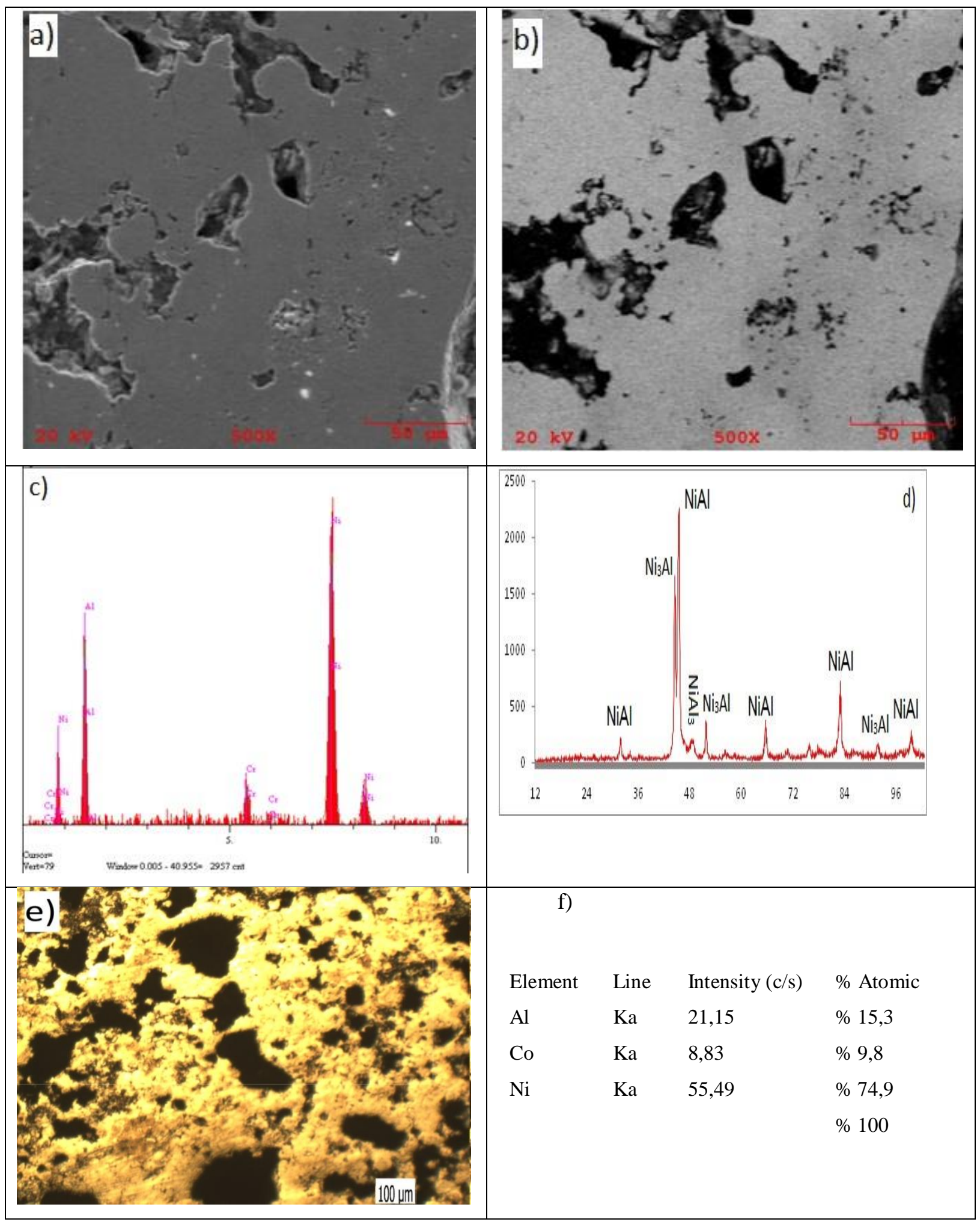

Figure 4: a) SEM, b) BSE, c) EDS graph, d) XRD, e) optical microscope image, f) EDS composition ratios of the $\mathrm{Cr}$ reinforced $\mathrm{NiAl}$ alloys 


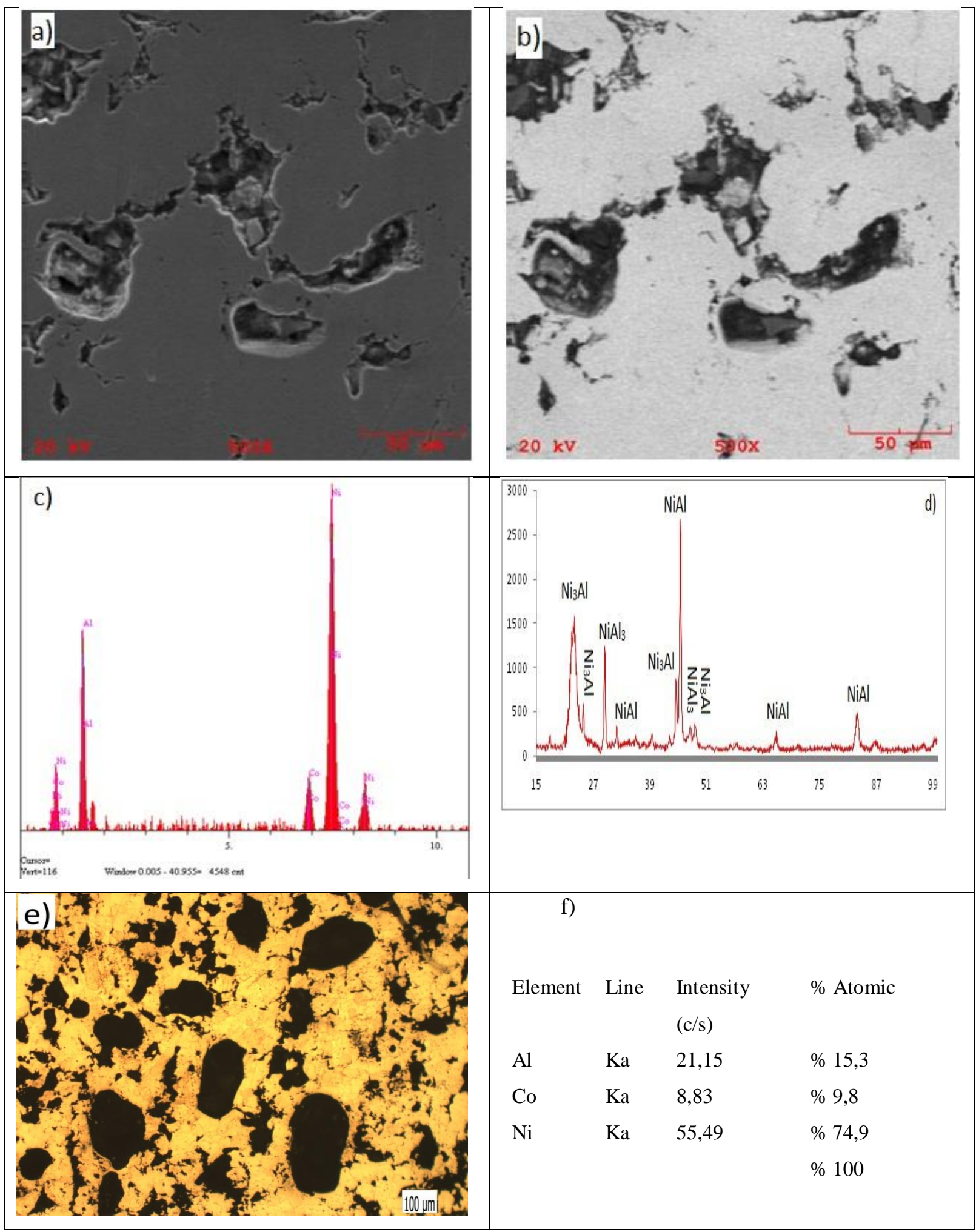

Figure 5: a) SEM, b) BSE, c) EDS graph, d) XRD, e) optical microscope image, f) EDS composition ratios of the Co reinforced $\mathrm{NiAl}$ alloys

\section{Conclusions}

In this study, by using SHS method, $50 \% \mathrm{Ni}-50 \% \mathrm{Al}$ powders were reinforced with $10 \% \mathrm{Co}$ and $10 \% \mathrm{Cr}$ and sample production was carried out and microstructure and microhardness analysis of samples were performed. According to the data obtained; 
- It was found that $\mathrm{Co}$ and $\mathrm{Cr}$ additive increases the microhardness values of $\mathrm{NiAl}$ at different rates. The highest hardness of $\mathrm{Cr}$ alloy specimens was $578 \mathrm{HV}$, while Co alloy specimens had $523 \mathrm{HV}$. The mean hardness of $\mathrm{Cr}$ alloy samples was 77.6 HV harder than the mean hardness of Co alloyed samples.

- Based on the optical microscope and SEM-BSE images, the samples produced were found to have high porosity. This porosity is thought to be an important factor in microhardness results.

- The most common $\mathrm{NiAl}$ and $\mathrm{Ni}_{3} \mathrm{Al}$ phases and low $\mathrm{NiAl}_{3}$ phases were determined in the $\mathrm{Cr}$ alloyed $\mathrm{NiAl}$ sample. Co alloyed $\mathrm{NiAl}$ sample has more $\mathrm{NiAl}$ phase and low $\mathrm{Ni}_{3} \mathrm{Al}$ and $\mathrm{NiAl}_{3}$ phases.

\section{Acknowledgements}

This study was supported by YTU BAP Coordination Unit as project FYL-2018-3354. We would like to thank YTU BAP Coordinator for their support.

\section{References}

[1] Li, Y., Liu, Y., Geng, H., Nie, D. (2006). Synthesis and cladding of $\mathrm{Ni}_{3} \mathrm{Al}$ intermetallic on steel substrate by laser controlled reactive synthesis, Journal of Materials Processing Technology 171 405-410.

[2] Wang,Y., Chen,W. (2004) .Microstructures, properties and high-temperature carburization resistances of HVOF thermal sprayed NiAl intermetallic-based alloy coatings, Surface and Coatings Technology 183 18-28.

[3] Brammer, M. (2011). Improving the phase stability and oxidation resistance of $\beta$-NiAl, MSc Thesis, Iowa StateUniversity, Ames, Iowa.

[4] Morsi, K. (2001). Review: reaction synthesis processing of $\mathrm{Ni}-\mathrm{Al}$ intermetallic materials. Materials Science and Engineering A299 1-15.

[5] Dey G. K. (2003). Physical metallurgy of nickel aluminides. Sadhana 28(1 \& 2), 247-262

[6] La, P.,Bai, M., Xue, Q., Liu, W. (1999). A study of Ni3Al coating on carbon steel surface via the SHS castin groute, Surface and Coatings Technology 113 44-51.

[7] Kaya M., Buğutekın A.,Orhan N. (2010)The effect of porosity on thermal conductivity of the porous NiTi SMA fabricated by SHS. Journal Of Optoelectronics And Advanced Materials. 12(8), 1250 - 1255.

[8] Kovalev A.I., Barskaya R.A., Wainstein D.L. (2003). Effect of alloying on electronic structure, strength and ductility characteristics of nickel aluminide. Surface Science, 532, 35 40

[9] Bochenek K., Basista M. (2015). Advances in processing of NiAl intermetallic alloys and composites for high temperature aerospace applications. 79, 136-146 
[10] Kılıç, M. (2015). Kendi ilerleyen yüksek sıcaklık sentezi ile fonksiyonel derecelendirilmiş intermetalik malzemelerin üretimi ve mikroyapılarının incelenmesi, Batman Üniversitesi Yaşam Bilimleri Dergisi; 5(2) 87-98.

[11] Ulu, R. 2013. Alaşım elementlerinin nial alaşımlarının mikroyapı ve mekanik özelliklerine etkisi. Yüksek Lisans Tezi, Karabük Üniversitesi Fen Bilimleri Enstitüsü, Karabük.

[12] Kilıç, M. (2014). NiTi ve Ni3Al fonksiyonel derecelendirilmiş malzemesinin reaksiyon sentezlemesi yöntemiyle üretilmesinin araştırılması. Doktora Tezi. Fırat Üniversitesi Fen Bilimleri Enstitüsü, Elazı ğ

[13] Kılıç, M., Bekten, M., Özdemir, N. (2019). SHS işlemi sonrası sinterleme işleminin intermetalik kaplamaya etkisinin incelenmesi, Frrat Üniversitesi Müh. Bil. Dergisi 31(1), 167-176.

[14] Tosun G., Özler L., Kaya M., Orhan N. (2008). SHS yöntemi ile üretilen niti alaşımlarının gözenek oranının incelenmesi. 5th IPMC. Ankara

[15] Chen, L., Han, Y., (2002) . The microstructure and compressive properties in NiAl(Co) alloys by HPXD technique", Materials Science and Engineering A329-331. 725728.

[16] Kiyotakai, M., Khan T. İ., Ohmi T., Kudoh, M. (2001), Reactive casting of B2 Ni-AlCo ternary intermetallic alloys, Materials Transactions. 42(2), $263-268$.

[17] Cotton J.D. 1991. The influence of chromium on structure and mechanical properties of b2 nickel aluminide alloys. PhD Thesis, University of Florida.

[18] Cao, Y., Zhu, P., Zhu, J., Liu, Y. (2016).First-principles study of NiAl alloyed with Co, Computational Materials Science. 111 34-40

[19] Ozdemir O., Zeytin S.,Bindal C. (2010). Characterization of NiAl with cobalt produced by combustion synthesis. Journal of Alloys and Compounds. 508, 216-221. 